DOI.

https://doi.org/10.22219/fths.v2i2

Received: Mei 2019

Accepted: Juni 2019

Available online: Juli 2019

\title{
Ekstraksi Gelatin Dari Kulit Kelinci Lokal Jawa (Lepus negricollis) Dengan Variasi Jenis Pelarut Dalam Suhu Ekstraksi Serta Aplikasinya Pada Bakso Kelinci
}

\author{
Putri Adek Putro ${ }^{1}$, Mochammad Wachid ${ }^{1}$, Noor Harini ${ }^{1 *}$ \\ ${ }^{1}$ Program Studi Teknologi Pangan, Fakultas Pertanian Peternakan, Universitas Muhammadiyah \\ Malang, Malang, Indonesia \\ *Corresponding author email: harini@umm.ac.id
}

\begin{abstract}
Gelatin is a protein obtained from animal collagen tissue found in warts, bones and connective tissue that is hydrolyzed acidic or basic. The purpose of this study was to determine the different effects of $\mathrm{HCl}$ and acetic acid and different extraction temperatures on the production of local rabbit skin gelatin so that the best treatment was obtained in producing gelatin and to determine the effectiveness of local rabbit skin gelatin in rabbit meatball processing. This research was conducted in two stages. The first stage uses a nested random design, namely the extraction of gelatin from the local rabbit skin with different types of acids ( $\mathrm{HCl} 3 \%$ and acetic acid 3\%) and extraction temperature $\left(50^{\circ} \mathrm{C}, 60\right.$ ${ }^{\circ} \mathrm{C}, 70^{\circ} \mathrm{C}$ and $80{ }^{\circ} \mathrm{C}$ ). The parameters observed were yield, moisture content, ash content, protein content, viscosity, pH, and color. The best treatment of Local rabbit skin gelatin based on the SNI approach is in the P1T3 treatment, that treatment soaking with acetic acid and extraction temperature of $70^{\circ} \mathrm{C}$ with a yield value of $13.11 \%$, moisture content $5.503 \%$, ash content $1.143 \%$, protein content $63.49 \%$, viscosity $4.466 \mathrm{cP}$, gel strength 210.532 grams Bloom, and pH 3,967. The second step was making meatballs by comparing the addition of gelatin from local rabbit skin extraction with the best treatment of $3 \%$, commercial gelatin 3\% and without gelatin. The parameters observed included protein content, ash content, moisture content, fat content, texture and organoleptic. Based on observations of the addition of gelatin in rabbit bakso, increasing the value of protein content, texture, and ash content in bakso while the water and fat content in bakso decreased with the addition of gelatin.
\end{abstract}

Keywords: acid, gelatin extraction, local rabbit skin, extraction temperature, rabbit meatball

\section{PENDAHULUAN}

Gelatin adalah protein yang diperoleh dari jaringan kolagen hewan yang terdapat pada kulit, tulang dan jaringan ikat yang dihidrolisis secara asam atau basa. Gelatin merupakan golongan protein larut air yang bersifat sebagai gelling agent atau bahan pengental tambahan pada makanan. Produksi gelatin di dunia dapat mencapai 326.000 ton per tahun. Penggunaan kulit atau tulang babi dan sapi pada produksi pembuatan gelatin menimbulkan banyak permasalahan di 
kalangan masyarakat terutama di Indonesia ini yang mayoritas penduduknya adalah muslim. Pemanfaatan sumber lain untuk bahan baku pembuatan gelatin, seperti pemanfaatan kulit kelinci merupakan cara alternatif untuk mengatasi permasalahan tersebut.

Penggunaan kulit kelinci berpotensi untuk diekstrak menjadi gelatin, karena telah ada penelitian sebelumnya yang menyatakan ekstraksi gelatin kulit kelinci Rex mengahsilkan nilai protein sebesar 70,3\%, viskositas $11,17 \mathrm{cP}$, kekuatan gel $187 \mathrm{~g}$ bloom, rendemen 8,26\%, kadar air 6,62\%, kadar abu 1,5\%. Selain itu, selama ini limbah kulit kelinci belum dimanfaatkan secara optimal. Limbah kulit kelinci biasanya hanya dikubur setelah proses pemotongan. Menurut BPS Kab Malang (2018) menyatakan bahwa jumlah konsumsi kelinci di kabupaten Malang mencapai 42.606 ekor kelinci per tahun. Sehingga limbah kulit kelinci yang dihasilkan juga sangat besar. Penggunaan kelinci Jawa atau Lokal dikarenakan pedagang sate kelinci menggunakan kelinci Lokal atau Jawa untuk digunakan.

Bakso merupakan bahan pangan yang terbuat dari daging ayam, sapi atau ikan yang telah dihaluskan dan dicampur dengan bahan tambahan lain serta bumbu-bumbu. Umumnya proses emulsifikasi pada pembuatan bakso kurang sempurna dan tekstur bakso kurang kenyal. Penambahan gelatin ditujukan untuk meningkatkan proses emulsifikasi dan kekenyalan bakso kemudian membandingkan karakteristik produk yang ditambahkan gelatin kulit kelinci perlakuan terbaik dengan gelatin komersil.

\section{METODE PENELITIAN}

\section{Bahan}

Bahan yang digunakan pada penelitian ini yaitu kulit jenis Lokal Jawa yang berumur 8 bulan dengan berat $3 \mathrm{~kg}$, kelinci yang diperoleh dari peternak kelinci di Kota Batu.

Alat

Alat yang digunakan pada penelitian ini adalah waterbath Memmert Tipe W-150, tanur Ney Tipe M-525 series II, HDPE, chabinet dryer, timbangan anlitik Ohaus PA413, viscometer VT-RiOn type t225, tekstur analyser Shimadzu Ez`sx 100, oven MMM Einrichtungen ecoll55, dan blender Philips HR-2874.

\section{Ekstraksi Gelatin}

\section{Konversi Kolagen Menggunakan Pelarut}

Kulit kelinci dicuci dari kotoran dan sisia darah yang menempel. Kemudian kulit kelinci direndam menggunakan kapur sebanyak 2\% selama 24 jam untuk mempermudah proses pencabutan bulu. Setelah bulu, sisa lemak dan kotoran pada kulit kelinci hilang, maka dilakukan pencucian hingga bersih dan tiriskan. Kulit kelinci tersebut dikecilkan ukurannya untuk memperluas permukaan sehingga mempermudah proses ekstraksi, kemudian ditimbang 
masing-masing 45 gram untuk setiap perlakuan. Setelah itu, kulit kelinci direndam dengan larutan $\mathrm{HCl} 3 \%(\mathrm{v} / \mathrm{v})$ dan Asam Asetat 3\% (v/v) selama 24 jam dengan perbandingan kulit dan pelarut 1:2 (b/v) untuk merubah struktur triple heliks kolagen menjadi ikatan a heliks yang mudah larut air ketika ekstraksi.

\section{Ekstraksi Menggunakan Suhu}

Kulit kelinci hasil rendaman dicuci menggunakan air mengalir sampai $\mathrm{pH}$ 7 atau netral kemudian diekstraksi dengan pelarut aquades dengan perbandingan $1 ; 2(\mathrm{~b} / \mathrm{v})$ dengan variasi suhu $50^{\circ} \mathrm{C}, 60^{\circ} \mathrm{C}, 70^{\circ} \mathrm{C}$ dan $80^{\circ} \mathrm{C}$. Kemudian disaring filtratnya menggunakan kain saring hingga diperoleh Ossein. Ossein tersebut dituang pada loyang yang dilapisi plastik tahan panas. Pemekatan Ossein dengan dimasukkan pada lemari pendingin bersuhu $4-10^{\circ} \mathrm{C}$ hingga membentuk gel. Kemudian gel dikeringkan pada kabinet pada suhu $\pm 60^{\circ} \mathrm{C}$ selama 3 hari. Lembaran gelatin yang kering dihaluskan menggunakan blender hingga menjadi bubuk gelatin.

\section{Pembuatan Bakso}

Daging dicuci dan dipotong, kemudian digiling menggunakan blender dan penambahan es batu. Kemudian dicampur dengan tepung tapioka dan bumbubumbu penyedap rasa untuk meningkatkan cita rasa bakso. Selain itu, gelatin dilarutkan dengan air sebanyak 3\% dari berat bakso dan ditambahkan pada adonan bakso. Kemudian bakso dicetak bulat-bulat dan merebus bakso (50 g) selama 10-15 menit. Bakso yang telah matang kemudian ditiriskan didalam suatu wadah.

\section{Parameter Penelitian}

Analisis yang dilakukan pada bahan baku kulit kelinci meliputi analisis kadar air, abu, protein, dan lemak. Sedangkan pada gelatin kulit kelinci yakni rendemen, kadar air, abu, protein, viskositas, pH, kekuatan. Sementara pada bakso yakni kadar air, abu, protein, lemak, tekstur, dan uji organoleptik (rasa, aroma, kekenyalan, dan kenampakan).

\section{Rancangan Percobaan dan Analisa Data}

Metode penelitian ini dilakukan dengan dua tahap, tahap yang pertama yaitu pembuatan gelatin dari kulit kelinci lokal Jawa dengan penggunaan asam yang berbeda dan perbedaan suhu ekstraksi, sedangkan untuk tahap yang kedua yaitu aplikasi gelatin pada pembuatan bakso kelinci.

Rancangan percobaan tahap pertama adalah Rancangan Acak Tersarang (Nested) dengan 2 faktor dan 3 ulangan. Adapun faktor pertama yaitu perbedaan jenis pelarut pada proses perendaman dengan 2 level, yaitu asam asetat $3 \%$ dan $\mathrm{HCl} 3 \%$. Perlakuan kedua yang digunakan adalah suhu ekstraksi dengan 3 level, yaitu $50^{\circ} \mathrm{C}, 60^{\circ} \mathrm{C}, 70^{\circ} \mathrm{C}$ dan $80^{\circ} \mathrm{C}$. 
Penelitian tahap kedua diperoleh gelatih dengan perlakuan terbaik pada tahap pertama yang akan diaplikasikan pada penelitian tahap kedua. Penelitian tahap kedua adalah pembuatan bakso dengan penambahan gelatin perlakuan terbaik, gelatin komersial dan non gelatin. Rancangan percobaan tahan kedua ini adalah RAK Sederhana dengan 1 faktor 3 variasi perlakuan dan 8 ulangan.

Analisis data dari hasil penelitian tahap pertama yaitu ekstraksi gelatin dari kulit kelinci lokal Jawa menggunakan uji sidik ragam (Annova) untuk mengetahui pengaruh dari perlakuan. Apabila hasil analisa menunjukkan berpengaruh nyata, maka jika ada interaksi antar faktor dilanjutkan dengan uji DMRT (Duncan's Multiple Range Test) untuk perlakuan berbeda nyata $\alpha=1 \%$ (Hanafiah, 2003). Penentuan untuk perlakuan terbaik menggunakan uji modus membandingkan parameter penelitian dengan SNI. Hasil dari perlakuan terbaik akan dibandingkan dengan perlakuan kontrol dan gelatin komersil dipasar.

\section{HASIL DAN PEMBAHASAN}

\section{Karakteristik Bahan Baku Kulit Kelinci}

Bahan baku yang digunakan dalam pembuatan gelatin pada penelitian ini adalah kulit kelinci jenis Lokal atau Jawa yang beurumur 7 bulan dan memiliki berat sekitar $3 \mathrm{~kg}$. Hasil analisis bahan baku kulit kelinci lokal Jawa dapat dilihat pada Tabel 1 .

Tabel 1. Hasil Analisis Kulit Kelinci

\begin{tabular}{ccccc}
\hline No. & Parameter & $\begin{array}{c}\text { Jumlah } \\
(\%) *\end{array}$ & $\begin{array}{c}\text { Jumlah } \\
(\%) * *\end{array}$ & $\begin{array}{c}\text { Jumlah } \\
(\%) * * *\end{array}$ \\
\hline 1. & Kadar air & 65,9 & 66,81 & 66,08 \\
2. & Kadar abu & 3,49 & 1,97 & 2,73 \\
3. & Lemak & 5,6 & 3,03 & 3,12 \\
4. & Protein & 22,98 & 30,1 & 28,04 \\
\hline
\end{tabular}

Sumber: *)Brown(1997)

**)Cahyaningrum (2016)

***)Hasil Pengujian Laboratorium (2019)

Hasil tabel diatas menunjukkan bahwa kulit kelinci Lokal memiliki kandungan protein yang tinggi sehingga berpotensi sebagai sumber pembuatan gelatin . Menurut Hastutiningrum (2009) kulit hewan terdiri atas protein, yang apabila dihidrolisis dapat menghasilkan kolagen yang baik untuk bahan pembuatan gelatin. gelatin sendiri merupakan sumber protein yang terbentuk akibat hidrolisis kolagen. Kolagen adalah suatu jenis protein yang tersusun dari beberapa asam amino. Menurut (Retno,2012) jumlah kolagen dalam tubuh hewan terdapat sekitar $30 \%$ dari total protein tubuh.

Umur ternak mempengaruhi kandungan protein pada kulit hewan, semakin bertambahnya umur hewan maka protein kolagennya semakin bertambah pula. Menurut Cole (2000), umur ternak berpengaruh terhadap 
kandungan kolagen pada kulit hewan, umur ternak dapat memberikan efek penting pada produk yang terbuat dari kolagen pada kulit hewan.

\section{Karakteristik Gelatin Kulit Kelinci Lokal Jawa}

\section{Kadar Air}

Tabel 2. Rerata Nilai Kadar Air Gelatin Kulit Kelinci Perlakuan Jenis Pelarut dalam Suhu Ekstraksi

\begin{tabular}{lc}
\hline \multicolumn{1}{c}{ Perlakuan } & Kadar air (\%) \\
\hline $\mathrm{HCl} 3 \%$ dalam suhu ekstraksi $50^{\circ} \mathrm{C}$ & $8,87 \pm 1,41^{\mathrm{b}}$ \\
$\mathrm{HCl} 3 \%$ dalam suhu ekstraksi $60^{\circ} \mathrm{C}$ & $6,91 \pm 1,14^{\mathrm{ab}}$ \\
$\mathrm{HCl} 3 \%$ dalam suhu ekstraksi $70^{\circ} \mathrm{C}$ & $5,50 \pm 0,55^{\mathrm{ab}}$ \\
$\mathrm{HCl} 3 \%$ dalam suhu ekstraksi $80^{\circ} \mathrm{C}$ & $4,48 \pm 0,85^{\mathrm{a}}$ \\
Asam asetat $3 \%$ dalam suhu ekstraksi $50^{\circ} \mathrm{C}$ & $12,62 \pm 2,12^{\mathrm{b}}$ \\
Asam asetat $3 \%$ dalam suhu ekstraksi $60^{\circ} \mathrm{C}$ & $11,04 \pm 0,90^{\mathrm{b}}$ \\
Asam asetat $3 \%$ dalam suhu ekstraksi $70^{\circ} \mathrm{C}$ & $8,47 \pm 1,18^{\mathrm{ab}}$ \\
Asam asetat $\%$ dalam suhu ekstraksi $80^{\circ} \mathrm{C}$ & $6,34 \pm 0,63^{\mathrm{ab}}$ \\
\hline
\end{tabular}

Angka-angka yang diikuti oleh huruf yang berbeda menunjukkan perbedaan nyata menurut uji Duncan a $1 \%$.

Hasil penelitian ini sesuai dengan pendapat Sompie (2015) yang menyatakan bahwa nilai kadar air cenderung menurun dengan semakin meningkatnya suhu ekstraksi. Soeparno (2005) juga menyatakan bahwa menurunnya kadar air gelatin diakibatkan oleh suhu ekstraksi yang tinggi, hal ini disebabkan karena proses denaturasi yang terjadi akan mengakibatkan perubahan molekul dan jumlah air yang terikat menjadi lebih lemah dan menurun.

Perbedaan nilai kadar air bisa dipengaruhi oleh perbedaan kemampuan jenis pelarut dalam mengisolasi kolagen kulit kelinci Lokal Jawa menjadi gelatin. Penggunaan $\mathrm{HCl}$ memiliki nilai kadar air lebih rendah dibandingkan dengan penggunaan asam asetat. Hal ini dikarenakan penggunaan asam yang kuat mengakibatkan reaksi berjalan dengan cepat, sehingga ikatan peptida yang terputus lebih banyak yang mengakibatkan air bebas yang tersedia juga lebih banyak dan menguap saat proses pengeringan sehingga menjadikan kadar air menurun.

\section{Kadar Abu}

Nilai kadar abu yang dihasilkan tersebut kurang dari 3,25\% sehingga sesuai dan memenuhi standar SNI yaitu maksimum 3,25\%. Kadar abu dapat dipengaruhi oleh proses pencucian atau demineralisasi bahan baku. 
Tabel 3. Rerata Nilai Kadar Abu Gelatin Kulit Kelinci Perlakuan Jenis Pelarut dalam Suhu Ekstraksi

\begin{tabular}{cc}
\hline \multicolumn{1}{c}{ Perlakuan } & Kadar Abu (\%) \\
\hline (HCl 3\% dalam suhu ekstraksi $\left.50^{\circ} \mathrm{C}\right)$ & $2,20 \pm 0,17^{\mathrm{ab}}$ \\
$\left(\mathrm{HCl} 3 \%\right.$ dalam suhu ekstraksi $\left.60^{\circ} \mathrm{C}\right)$ & $1,73 \pm 0,13^{\mathrm{ab}}$ \\
$\left(\mathrm{HCl} 3 \%\right.$ dalam suhu ekstraksi $\left.70^{\circ} \mathrm{C}\right)$ & $1,43 \pm 0,13^{\mathrm{a}}$ \\
$\left(\mathrm{HCl} 3 \%\right.$ dalam suhu ekstraksi $\left.80^{\circ} \mathrm{C}\right)$ & $2,92 \pm 0,05^{\mathrm{b}}$ \\
$\left(\right.$ Asam asetat 3\% dalam suhu ekstraksi $\left.50^{\circ} \mathrm{C}\right)$ & $3,06 \pm 0,06^{\mathrm{b}}$ \\
(Asam asetat 3\% dalam suhu ekstraksi $\left.60^{\circ} \mathrm{C}\right)$ & $2,72 \pm 0,10^{\mathrm{b}}$ \\
(Asam asetat 3\% dalam suhu ekstraksi $\left.70^{\circ} \mathrm{C}\right)$ & $2,14 \pm 0,13^{\mathrm{ab}}$ \\
(Asam asetat 3\% dalam suhu ekstraksi $\left.80^{\circ} \mathrm{C}\right)$ & $3,11 \pm 0,86^{\mathrm{b}}$ \\
Angka-angka yang diikuti oleh huruf yang berbeda menunjukkan perbedaan nyata menurut uji \\
Duncan a 1\%.
\end{tabular}

Perlakuan penggunaan pelarut $\mathrm{HCl}$ menghasilkan nilai kadar abu lebih rendah dibanding dengan pelarut asam asetat. Hal ini dikarenakan semakin kuat asam maka jumlah mineral dalam ossein semakin rendah. Hal ini didukung oleh Mulyani dkk. (2012) yang menyatakan bahwa pelarut asam melarutkan kalsium yang akan larut dalam pelarut sehingga jumlah mineral yang terdapat pada ossein berkurang. Selain perbedaan jenis pelarut, suhu ekstraksi juga berpengaruh terhadap nilai kadar abu gelatin kulit kelinci Lokal. Semakin tinggi suhu ekstraksi gelatin maka nilai kadar abu semakin rendah. Hal ini dikarenakan semakin tinggi suhu ektraksi akan menyebabkan melemahnya ikatan mineral yang mengakibatkan rusaknya ikatan mineral dan menurunkan nilai kadar abu.

\section{Rendemen}

Tabel 4. Rerata Nilai Rendemen Gelatin Kulit Kelinci Perlakuan Jenis Pelarut dalam Suhu Ekstraksi

\begin{tabular}{lc}
\hline \multicolumn{1}{c}{ Perlakuan } & Rendemen (\%) \\
\hline $\mathrm{HCl} 3 \%$ dalam suhu ekstraksi $50^{\circ} \mathrm{C}$ & $8,48 \pm 0,25^{\mathrm{b}}$ \\
$\mathrm{HCl} 3 \%$ dalam suhu ekstraksi $60^{\circ} \mathrm{C}$ & $10,31 \pm 0,18^{\mathrm{cd}}$ \\
$\mathrm{HCl} 3 \%$ dalam suhu ekstraksi $70^{\circ} \mathrm{C}$ & $13,11 \pm 0,85^{\mathrm{e}}$ \\
$\mathrm{HCl} 3 \%$ dalam suhu ekstraksi $80^{\circ} \mathrm{C}$ & $11,32 \pm 0,14^{\mathrm{c}}$ \\
Asam asetat $3 \%$ dalam suhu ekstraksi $50^{\circ} \mathrm{C}$ & $6,14 \pm 0,17^{\mathrm{d}}$ \\
Asam asetat $3 \%$ dalam suhu ekstraksi $60^{\circ} \mathrm{C}$ & $8,01 \pm 0,11^{\mathrm{b}}$ \\
Asam asetat $3 \%$ dalam suhu ekstraksi $70^{\circ} \mathrm{C}$ & $10,97 \pm 0,45^{\mathrm{c}}$ \\
Asam asetat $3 \%$ dalam suhu ekstraksi $80^{\circ} \mathrm{C}$ & $9,06 \pm 0,39^{\mathrm{bc}}$ \\
\hline
\end{tabular}

Angka-angka yang diikuti oleh huruf yang berbeda menunjukkan perbedaan nyata menurut uji Duncan a $1 \%$. 
Pelarut $\mathrm{HCl}$ memiliki rendemen lebih tinggi dibanding dengan pelarut asam asetat. Hal ini diduga karena jumlah ion $\mathrm{H}+$ yang menghidrolisis kulit kelinci berbeda tergantung jenis asam yang digunakan, semakin banyak ion $\mathrm{H}+$ atau semakin kuat asam suatu pelarut maka jumlah rendemen juga semakin meningkat karena jumlah kolagen yang terurai semakin banyak. Peningkatan jumlah ion $\mathrm{H}+$ dapat mempercepat laju hidrolisis kolagen. Bila laju hidrolisis semakin besar maka pemecahan triple helix menjadi rantai $\alpha, b$ dan $\mathrm{y}$ juga semakin besar yang menyebabkan kolagen yang terkonversi menjadi gelatin semakin banyak Kolodziejska,dkk., (2017).

Suhu ekstraksi yang berbeda berpengaruh sangat nyata terhadap hasil nilai rendemen gelatin kulit kelinci yang dihasilkan. Berdasarkan tabel data di atas semakin tinggi suhu nilai rendemen juga meningkat. Menurut Ockerman dan Hansen (2000) menyatakan bahwa suhu ekstraksi yang tinggi akan meningkatkan rendemen karena sruktur kolagen terbuka dan mengakibatkan beberapa ikatan dalam molekul proteinnya terlepas. Sedangkan pada suhu $80^{\circ} \mathrm{C}$ dari kedua jenis pelarut mengalami penurunan nilai rendemen yaitu perlakuan pelarut $\mathrm{HCl}$ dengan suhu $80^{\circ} \mathrm{C}$ adalah $11,32 \%$ dan perlakuan pelarut asam asetat dengan suhu $80^{\circ} \mathrm{C} 9,06 \%$. Hal ini diduga karena suhu ekstraksi yang terlalu tinggi akan menimbulkan adanya hidrolisis lanjutan sehingga sebagian gelatin terdegradasi dan menyebabkan turunnya jumlah nilai gelatin dari kulit kelinci lokal Jawa.

\section{Protein}

Tabel 5. Rerata Nilai Kadar Protein Gelatin Kulit Kelinci Perlakuan Jenis Pelarut dalam Suhu Ekstraksi

\begin{tabular}{lc}
\hline \multicolumn{1}{c}{ Perlakuan } & Protein $(\%)$ \\
\hline $\mathrm{HCl} 3 \%$ dalam suhu ekstraksi $50^{\circ} \mathrm{C}$ & $52,21 \pm 3,77^{\mathrm{ab}}$ \\
$\mathrm{HCl} 3 \%$ dalam suhu ekstraksi $60^{\circ} \mathrm{C}$ & $57,82 \pm 0,80^{\mathrm{b}}$ \\
$\mathrm{HCl} 3 \%$ dalam suhu ekstraksi $70^{\circ} \mathrm{C}$ & $63,49 \pm 2,39^{\mathrm{b}}$ \\
$\mathrm{HCl} 3 \%$ dalam suhu ekstraksi $80^{\circ} \mathrm{C}$ & $45,41 \pm 4,29^{\mathrm{ab}}$ \\
Asam asetat 3\% dalam suhu ekstraksi $50^{\circ} \mathrm{C}$ & $43,52 \pm 7,82^{\mathrm{a}}$ \\
Asam asetat 3\% dalam suhu ekstraksi $60^{\circ} \mathrm{C}$ & $52,95 \pm 1,20^{\mathrm{ab}}$ \\
Asam asetat 3\% dalam suhu ekstraksi $70^{\circ} \mathrm{C}$ & $55,46 \pm 3,62^{\mathrm{ab}}$ \\
Asam asetat 3\% dalam suhu ekstraksi $80^{\circ} \mathrm{C}$ & $47,35 \pm 2,80^{\mathrm{ab}}$ \\
\hline
\end{tabular}

Angka-angka yang diikuti oleh huruf yang berbeda menunjukkan perbedaan nyata menurut uji Duncan a $1 \%$.

Jenis pelarut berpengaruh sangat nyata terhadap nilai kadar protein gelatin kulit kelinci yang dihasilkan. Nilai protein tertinggi ada pada perlakuan $\mathrm{HCl}$ yaitu $63,49 \%$ dan terendah ada pada perlakuan asam asetat 43,52\%. Penggunaan $\mathrm{HCl}$ menghasilkan nilai protein yang lebih tinggi dibandingkan dengan asam asetat. Hal ini dikarenakan semakin kuat asam yang digunakan 
maka pada proses curing dalam menghidrolisisi kolagen akan semakin optimal atau lebih banyak. Penggunaan asam asetat menghasilkan kadar protein yang paling rendah hal ini dikarenakan penguraian kolagen pada proses curing dengan asam asetat belum optimal. Astawan dkk. (2003) kadar protein dipengaruhi oleh proses curing, karena pada proses tersebut terjadi pemutusan ikatan hidrogen.

Semakin tinggi suhu yang digunakan kadar protein gelatin kulit kelinci lokal juga meningkat pula. Hal ini didukung oleh Ockerman dan Hansen (2000) menyatakan bahwa suhu ekstraksi yang tinggi akan meningkatkan nilai protein karena sruktur kolagen terbuka dan akibat beberapa ikatan dalam molekul proteinnya terlepas.

\section{Viskositas}

Tabel 6. Rerata Nilai Viskositas Gelatin Kulit Kelinci Perlakuan Jenis Pelarut dalam Suhu Ekstraksi

\begin{tabular}{lc}
\hline \multicolumn{1}{c}{ Perlakuan } & Viskositas(cP) \\
\hline $\mathrm{HCl} 3 \%$ dalam suhu ekstraksi $50^{\circ} \mathrm{C}$ & $5,92 \pm 0,51^{\mathrm{b}}$ \\
$\mathrm{HCl} 3 \%$ dalam suhu ekstraksi $60^{\circ} \mathrm{C}$ & $5,07 \pm 0,62^{\mathrm{ab}}$ \\
$\mathrm{HCl} 3 \%$ dalam suhu ekstraksi $70^{\circ} \mathrm{C}$ & $4,47 \pm 0,30^{\mathrm{ab}}$ \\
$\mathrm{HCl} 3 \%$ dalam suhu ekstraksi $80^{\circ} \mathrm{C}$ & $4,16 \pm 0,13^{\mathrm{a}}$ \\
Asam asetat 3\% dalam suhu ekstraksi $50^{\circ} \mathrm{C}$ & $5,94 \pm 0,56^{\mathrm{b}}$ \\
Asam asetat 3\% dalam suhu ekstraksi $60^{\circ} \mathrm{C}$ & $5,13 \pm 0,60^{\mathrm{ab}}$ \\
Asam asetat 3\% dalam suhu ekstraksi $70^{\circ} \mathrm{C}$ & $5,03 \pm 0,74^{\mathrm{ab}}$ \\
Asam asetat 3\% dalam suhu ekstraksi $80^{\circ} \mathrm{C}$ & $4,97 \pm 0,36^{\mathrm{ab}}$ \\
\hline Anta
\end{tabular}

Angka-angka yang diikuti oleh huruf yang berbeda menunjukkan perbedaan nyata menurut uji Duncan a $1 \%$.

Viskositas merupakan daya aliran molekul dalam suatu larutan. Nilai viskositas pada Tabel 6 diatas cenderung mengalami penurunan dengan semakin meningkatnya suhu ekstraksi hal ini dikarenakan suhu yang terlalu tinggi dapat menyebabkan putusnya ikatan hidrogen dan gugus hidroksil dari asam amino. Hal ini sesuai dengan pendapat Word \& Courts (1997) yang menyatakan bahwa suhu ekstraksi diatas $50^{\circ} \mathrm{C}$ menyebabkan kemampuan membentuk gel dan sifat fisik gelatin menurun, hal ini disebabkan oleh putusnya ikatan hidrogen dan gugus hidroksil dan asam amino. 


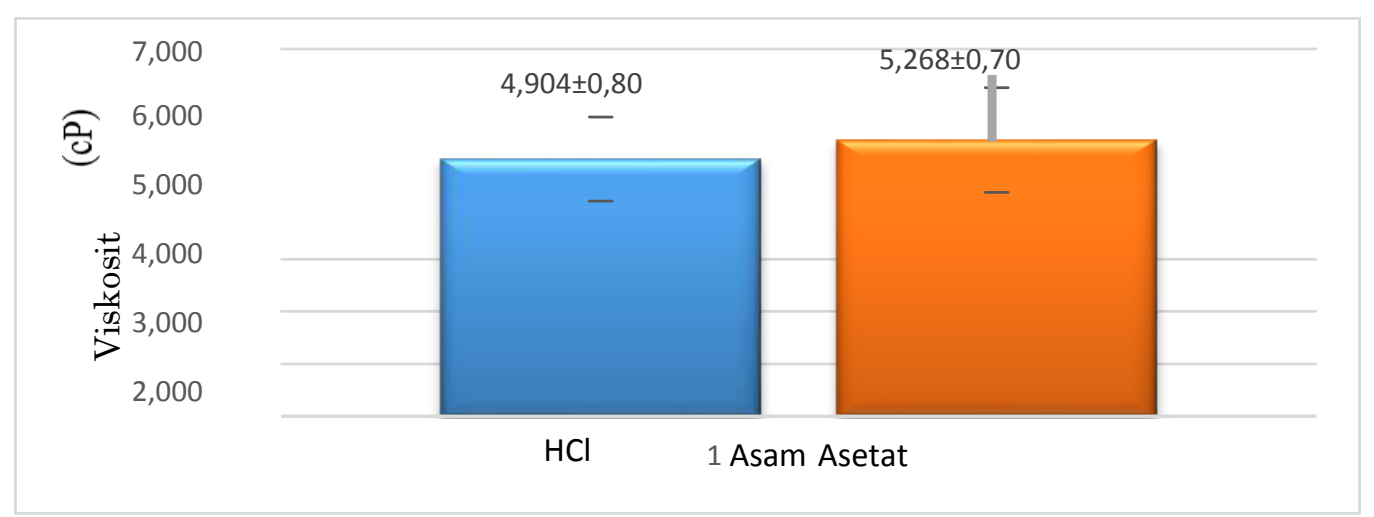

Gambar 1. Histogram Rerata Viskositas pada Perbedaan Jenis Pelarut

Semakin kuat jenis asam menghasilkan viskositas gelatin lebih rendah, hal ini dikarenakan semakin kuat jenis asam maka $\mathrm{pH}$ semakin rendah yang kemudian akan berlanjut pada pemutusan rantai asam amino menjadi lebih pendek yang mengakibatkan menurunnya nilai viskositas gelatin kulit kelinci yang dihasilkan. Hal ini didukung oleh Astawan dan Avina (2002) yang menyatakan bahwa tinggi atau rendahnya nilai viskositas gelatin dapat dipengaruhi oleh, $\mathrm{pH}$ dan konsentrasinya. Asam yang kuat dapat menyebabkan terputusnya rantai molekul dari gelatin, oleh karna itu gelatin dengan pelarut $\mathrm{HCl}$ memiliki visositas lebih kecil dari pelarut asam asetat.

\section{Derajat Keasaman $(\mathrm{pH})$}

Tabel 7. Rerata Nilai pH Gelatin Kulit Kelinci Perlakuan Jenis Pelarut dalam Suhu Ekstraksi

\begin{tabular}{lc}
\hline \multicolumn{1}{c}{ Perlakuan } & $\mathrm{pH}$ \\
\hline $\mathrm{P} 1(\mathrm{HCl})$ & $3,87 \pm 0^{\mathrm{a}}$ \\
$\mathrm{P} 2$ (asam asetat) & $5,05 \pm 0^{\mathrm{b}}$ \\
\hline
\end{tabular}

Angka-angka yang diikuti oleh huruf yang berbeda menunjukkan perbedaan nyata menurut uji Duncan a $1 \%$.

Nilai $\mathrm{pH}$ (potensial hidrogen) merupakan salah satu parameter yang penting dalam penentuan standart mutu gelatin karena $\mathrm{pH}$ dapat mempengaruhi sifat gelatin lainnya seperti viskositas dan kekuatan gel. Nilai $\mathrm{pH}$ pada gelatin dipengaruhi oleh jenis pelarut yang digunakan. Perbedaan jenis pelarut berpengaruh sangat nyata terhadap hasil nilai $\mathrm{pH}$ yang dihasilkan. Nilai $\mathrm{pH}$ dengan perendaman pelarut $\mathrm{HCl}$ memiliki $\mathrm{pH}$ lebih rendah (asam) yaitu 3,872 dibanding dengan perendaman pelarut asam asetat yaitu 5,053. Hal ini dikarenakan $\mathrm{HCl}$ merupakan asam kuat dan memiliki $\mathrm{pH}$ lebih rendah (asam) dibandingkan dengan asam asetat. Hal ini didukung oleh Nurimala, dkk (2006) yang menyatakan bahwa rendahnya nilai $\mathrm{pH}$ pada gelatin diakibatkan oleh penggunaan asam. Hal ini diduga masih ada sisa-sisa asam yang digunakan 
pada proses perendaman dengan pelarut asam yang masih terbawa saat proses ekstraksi.

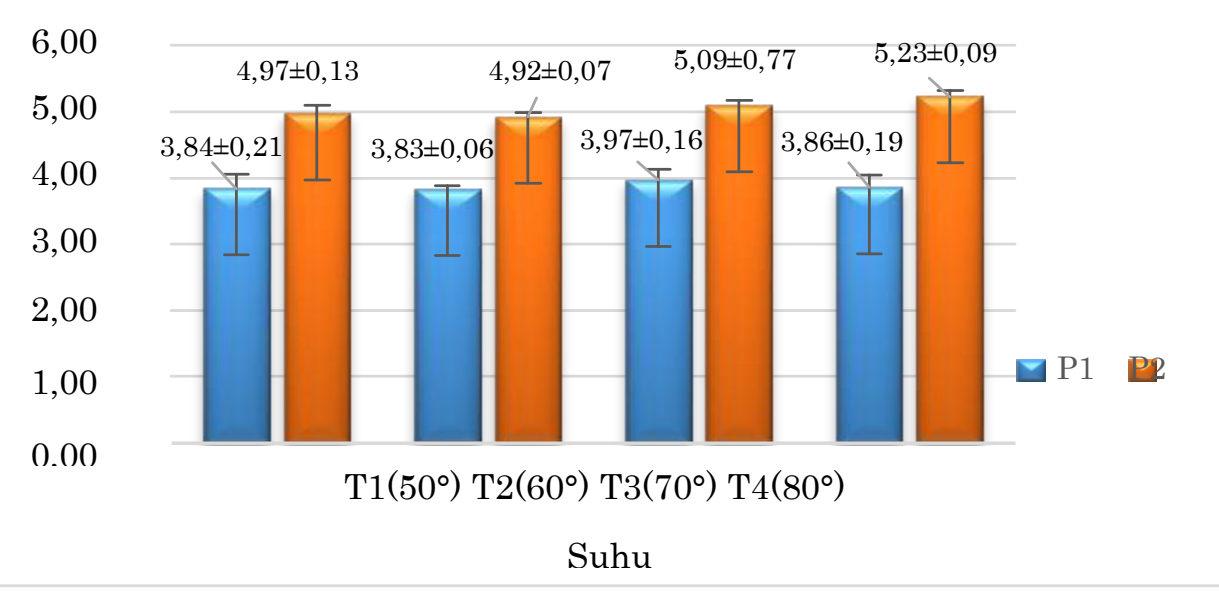

Gambar 2. Histogram Rerata pH pada Perbedaan Jenis Pelarut dan Suhu Ekstraksi

Suhu ekstraksi tidak berpengaruh terhadap nilai $\mathrm{pH}$ gelatin. Hasil rerata pH yang dihasilkan dari estraksi gelatin kulit kelinci ini masih memenuhi standar SNI gelatin yaitu 3,5-5,5 (GMIA, 2012).

\section{Kekuatan Gel}

Tabel 8. Rerata Nilai Kekuatan Gel Gelatin Kulit Kelinci Perlakuan Jenis Pelarut Dalam Suhu Ekstraksi

\begin{tabular}{lc}
\hline \multicolumn{1}{c}{ Perlakuan } & Kek. Gel (bloom) \\
\hline P1 (HCl) & $210,53 \pm 51,75^{\mathrm{a}}$ \\
P2 (asam asetat) & $310,66 \pm 51,37^{\mathrm{b}}$ \\
\hline
\end{tabular}

Angka-angka yang diikuti oleh huruf yang berbeda menunjukkan perbedaan nyata menurut uji Duncan a $1 \%$.

Menurut Taufik (2011) kekuatan gel berhubungan dengan kemampuan mengubah dengan kemampuan mengubah cairan menjadi padatan atau merubah sol menjadi gel yang bersifat reversible. Nilai kekuatan gel yang dihasilkan sesuai dengan standar SNI gelatin yaitu 75-300 bloom (SNI, 1995). Berdasarkan hasil tabel di atas menunjukkan asam kuat $\mathrm{HCl}$ memiliki nilai kekuatan gel lebih rendah, hal ini dikarenakan jenis larutan asam yang terlalu tinggi yang dapat merusak struktur gelatin sehingga gel gelatin tidak terbentuk. 


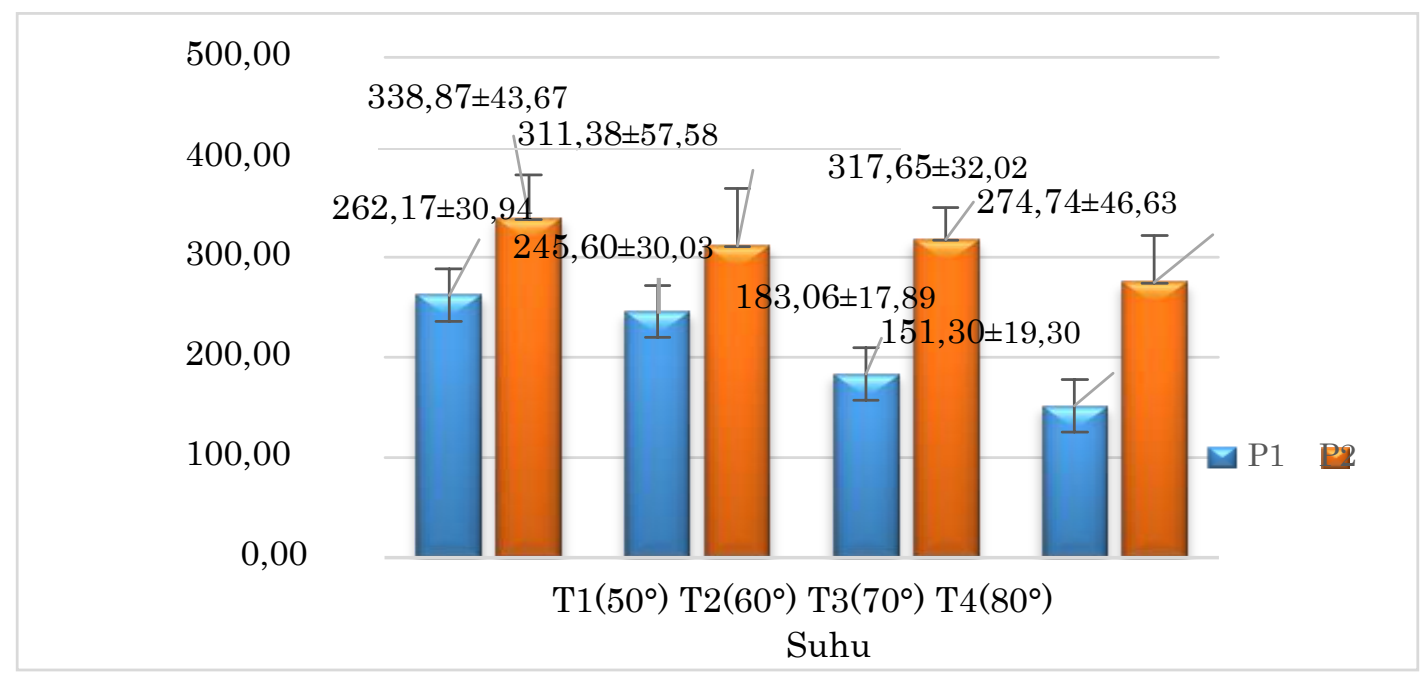

Gambar 3. Histogram Rerata Kekuatan Gel pada Perbedaan Jenis Pelarut dan Suhu Ekstraksi

Gambar 3 menunjukkan histogram rata-rata pengaruh suhu ekstraksi yang tidak berpengaruh terhadap nilai kekuatan gel gelatin. Suhu ekstraksi pada proses pembuatan gelatin kulit kelinci Lokal Jawa dapat memutus ikatan hidrogen serta gugus hidroksil dari asam amino. Ekstraksi gelatin dapat dilakukan pada suhu $50-100^{\circ} \mathrm{C}$ (Huda, dkk., 2013). Penggunaan suhu yang lebih dari $95^{\circ} \mathrm{C}$ dapat menurunkan sifat-sifat gelatin.

\section{Aplikasi Gelatin Pada Bakso Kelinci}

\section{Kadar Air}

Tabel 9. Nilai Rata-Rata Kadar Air Bakso Kelinci

\begin{tabular}{cc}
\hline Perlakuan & Kadar Air (\%) \\
\hline Tanpa Gelatin & $69,81 \pm 0,92^{\mathrm{c}}$ \\
Gelatin Kulit Kelinci & $63,67 \pm 0,93^{\mathrm{b}}$ \\
Gelatin Komersil & $60,64 \pm 0,38^{\mathrm{a}}$ \\
\hline
\end{tabular}

Angka-angka yang diikuti oleh huruf yang berbeda menunjukkan perbedaan nyata menurut uji Duncan a $1 \%$.

Berdasarkan hasil penelitian pada tabel 9 diatas menunjukkan bahwa kadar air yang dihasilkan pada pembuatan bakso daging kelinci memenuhi standar SNI yaitu menurut SNI (2004) menyatakan bahwa kadar air bakso maksimal adalah $70 \%$. Penambahan gelatin pada bakso kelinci mengakibatkan penurunan nilai kadar air, hal ini dikarenakan salah satu fungsi gelatin adalah mampu mengikat air. Menurut Edward (2000) yang menyatakan bahwa asam amino mempengaruhi kemampuan gelatin untuk mengikat air.

\section{Kadar Abu}


Hasil nilai kadar abu yang dihasilkan pada pembuatan bakso kelinci dengan semua perlakuan telah memenuhi standar SNI yaitu maksimal 3\%.

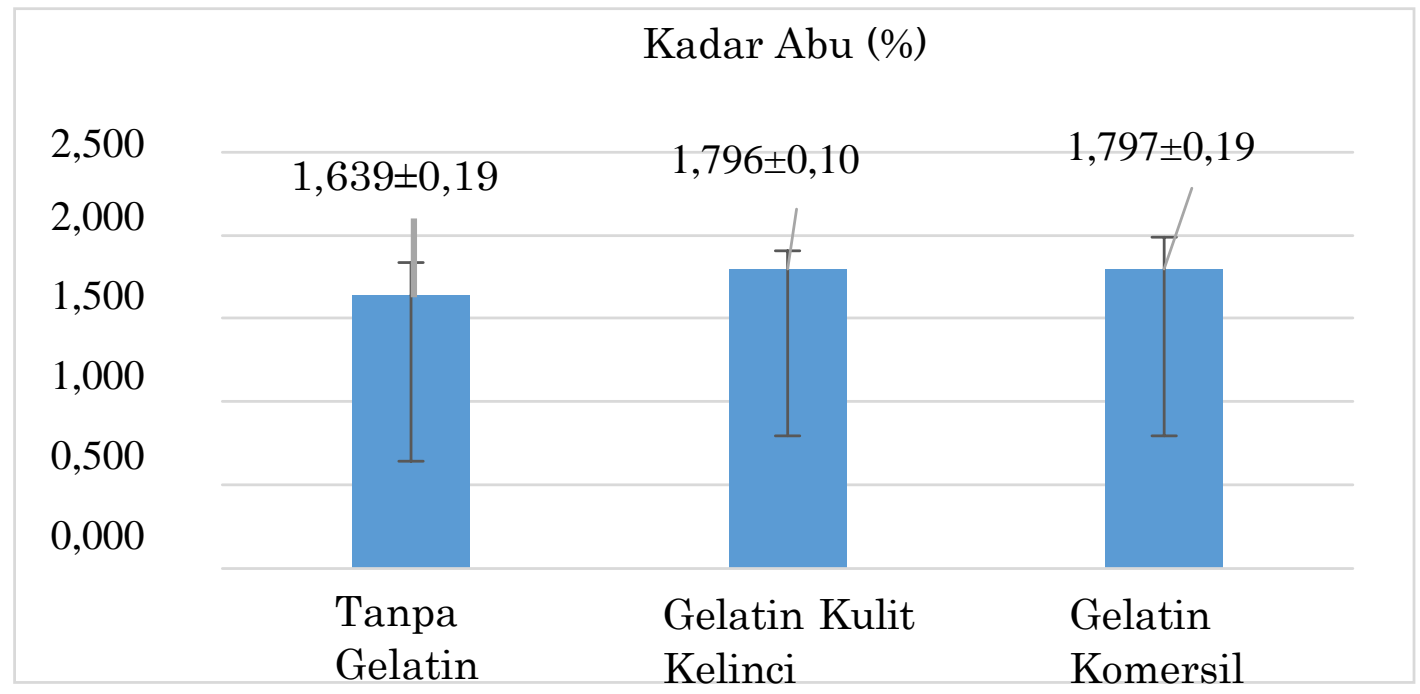

Gambar.4 Histogram Reratan Nilai Kadar Abu Bakso Kelinci

Menurut DetikFood (2014) menyatakan bahwa gelatin banyak mengandung mineral seperti selenium $2,8 \mathrm{mg}$, tembaga $0,2 \mathrm{mg}$, besi $1 \mathrm{mg}$, fosfor $20 \mathrm{mg}$, dan sodium $14 \mathrm{mg}$. Hal ini menyebabkan penambahan gelatin meningkatkan nilai kadar abu bakso kelinci. Kadar abu merupakan jumlah mineral yang terkandung dalam bahan pangan. Menurut Zahro (2013) yang menyatakan bahwa kadar abu merupakan residu anorganik dari hasil pembakaran atau hasil oksidasi komponen organik bahan pangan.

\section{Kadar Protein}

Tabel 10. Nilai Rata-Rata Kadar Protein Bakso Kelinci Perlakuan Kadar Protein (\%)

$\begin{array}{cr}\text { Tanpa Gelatin } & 8,76 \pm 0,20^{\mathrm{a}} \\ \text { elatin Kulit Kelinci } & 10,09 \pm 0,08^{\mathrm{b}} \\ \text { Gelatin Komersil } & 11,11 \pm 0,20^{\mathrm{c}}\end{array}$

Angka-angka yang diikuti oleh huruf yang berbeda menunjukkan perbedaan nyata menurut uji Duncan a $1 \%$.

Berdasarkan hasil Tabel 16 di atas menunjukkan bahwa dengan penambahan gelatin akan meningkatkan nilai protein bakso kelinci. Hal ini dikarenakan gelatin merupakan produk turunan protein yang tinggi kandungan proteinnya, sehingga dengan penambahan gelatin pada suatu produk akan meningkatkan kadar proteinnya. Hal ini didukung oleh Agustin dkk. (2005) yang menyatakan bahwa gelatin merupakan jenis protein yang di hasilkan dari proses ekstraksi jaringan kolagen hewan yang terdapat pada kulit, tulang dan jaringan ikat. Bakso dengan penambahan gelatin komersil memiliki kadar protein lebih 
tinggi dibanding dengan bakso dengan penambahan gelatin kulit kelinci. Hal ini dikarenakan gelatin komersil memiliki kandungan protein lebih tinggi dibanding dengan gelatin kulit kelinci.

\section{Kadar Lemak}

Hasil dari nilai kadar lemak yang dihasilkan pada pembuatan bakso kelinci dengan semua perlakuan telah memenuhi standar SNI (2004) yaitu maksimal 10\%.

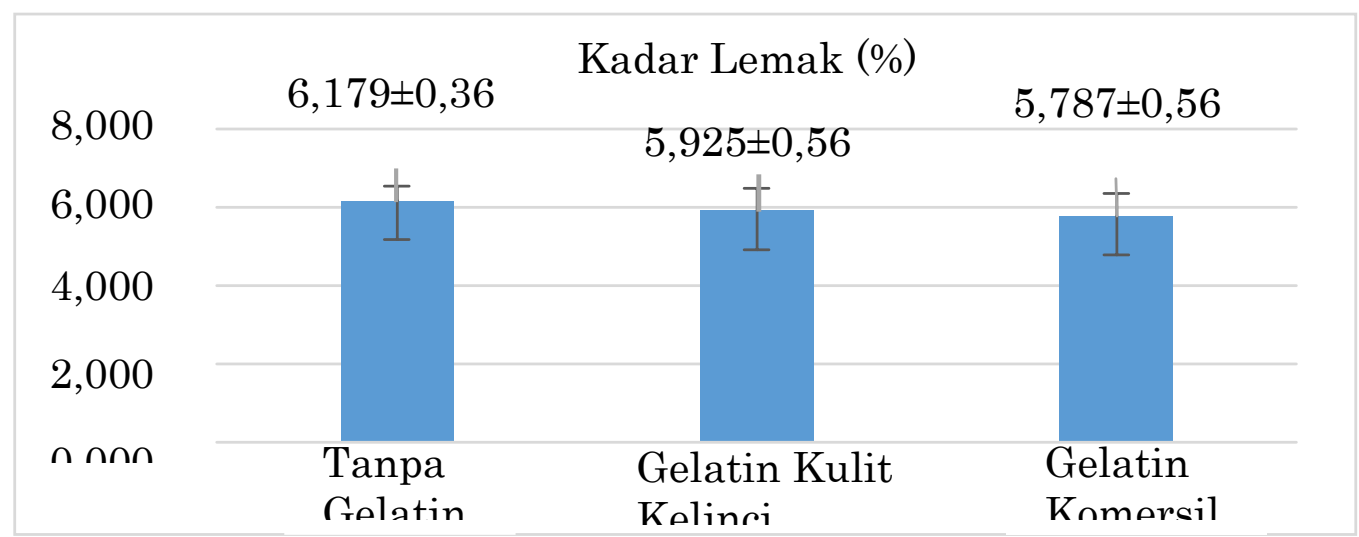

Gambar 5. Histogram Rerata Nilai Kadar Lemak Pada Bakso Kelinci

Hasil analisis kadar lemak dengan perlakan perbedaan jenis gelatin pada pembuatan bakso kelinci dapat dilihat pada Gambar di atas bahwa nilai kadar lemak yang dihasilkan telah memenuhi standar SNI yaitu di bawah 10\%. Hal ini menunjukkan bahwa kualitas bakso daging kelinci baik. Kadar lemak merupakan salah satu faktor penting dalam penentuan kualitas bakso. Hal ini dikarenakan kadar lemak pada bakso dapat mempengaruhi kekenyalan dan daya simpan bakso. Kadar lemak yang terkandung pada suatu bahan makanan dapat menghambat air yang mengikat myofibrin sehingga dapat menurunkan kekuatan gelnya.

\section{Tekstur}

Tabel 17. Nilai Rata-Rata Tekstur Bakso Kelinci

\begin{tabular}{cc}
\hline Perlakuan & Tekstur $\left(\mathrm{N} / \mathrm{mm}^{2}\right)$ \\
\hline Tanpa Gelatin & $17,73 \pm 0,32^{\mathrm{a}}$ \\
Gelatin Kulit Kelinci & $20,14 \pm 0,29^{\mathrm{c}}$ \\
Gelatin Komersil & $19,12 \pm 0,27^{\mathrm{b}}$ \\
\hline
\end{tabular}

Angka-angka yang diikuti oleh huruf yang berbeda menunjukkan perbedaan nyata menurut uji Duncan a $1 \%$.

Penambahan gelatin meningkatkan nilai tekstur pada bakso kelinci. Hal ini dikarenakan gelatin memiliki sifat mengikat air dan membentuk gel, sehingga denga penambahan gelatin tekstur bakso yang dihasilkan lebih keras. 
Hal ini sesuai dengan Sartika (2009) yang menyatakan bahwa pemberian gelatin dapat menyebabkan tekstur bahan pangan lebih kera atau kenyal. Menurut Parker (1999) menyatakan bahwa gelatin memiliki fungsi mengubah tekstur dengan cara membentuk jaringan dari molekul-molekul dalam bentuk sol yang telah menyerap air. Pembentukan gel karna penambahan gelatin merupakan suatu fenomena penggabungan atau pengikat silang rantai-rantai polimer membentuk jalinan tiga dimensi yang kontinyu, sehingga dapat menangkap air didalamnya menjadi struktur yang kompak dan kaku, yang tahan terhadap aliran di bawah tekanan.

\section{Organoleptik Bakso Kelinci}

\section{Aroma}

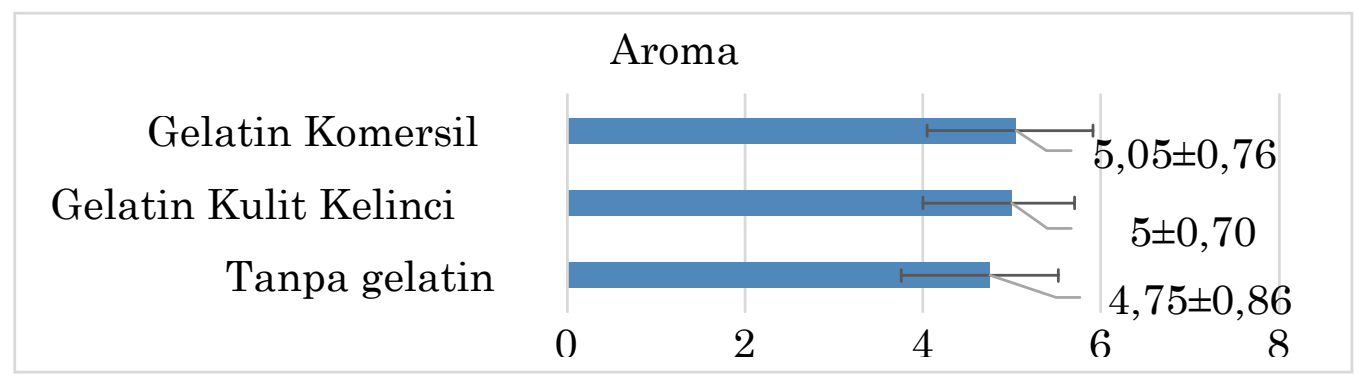

Gambar 6. Histogram Rerata Nilai Organoleptik Aroma Pada Bakso Kelinci

Aroma bakso kelinci dengan penambahan gelatin kelinci, gelatin komersil dan tanpa gelatin memiliki nilai yang berbeda. Bakso dengan tanpa gelatin memiliki nilai yang sangat rendah atau agak tidak disukai oleh panelis. Hal ini dikarenakan daging kelinci memiki bau yang sedikit anyir dan tanpa penambahan gelatin membuat bau anyir daging kelinci sedikit menonjol sehingga membuat nilai aroma dari panelis rendah. Menurut Aberle dkk. (2001) menyatakan bahwa rasa dan aroma daging berasal dari sejumlah bahan yang ada di dalam lemak dan bersifat menguap akibat pemanasan. Penambahan gelatin komersil dan gelatin kelinci memiliki nilai yang hampir sama dan memiliki nilai aroma yang sedap dari penilaian panelis. Hal ini dikarenakan dengan penambahan gelatin pada pembuatan bakso dapat mengurangi bau anyir pada daging kelinci. 
Rasa

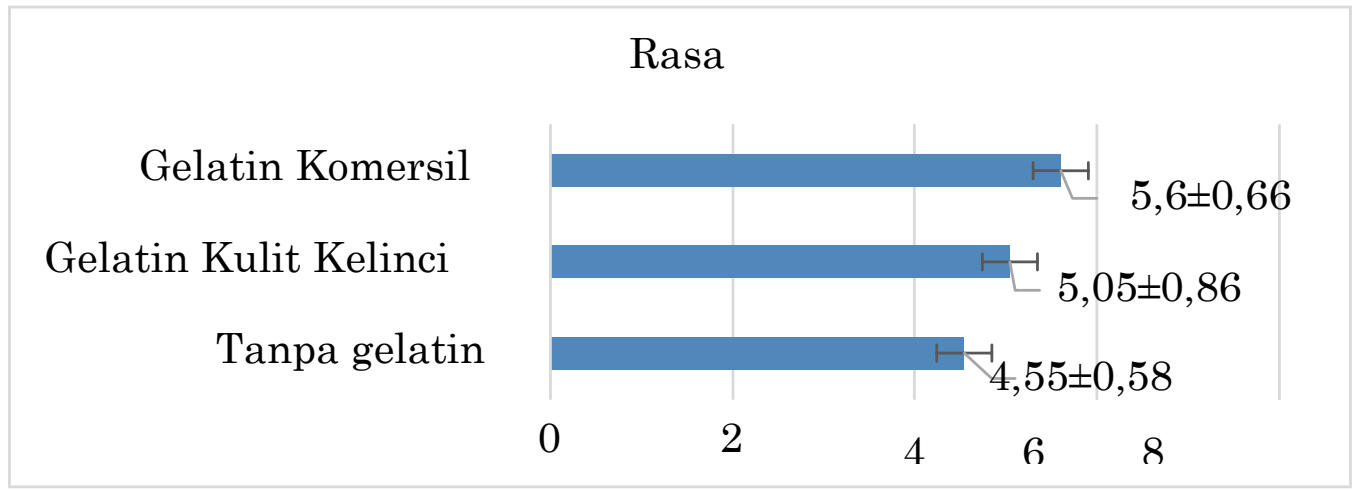

Gambar 7. Histogram Rerata Nilai Organoleptik Rasa Pada Bakso Kelinci

Rasa merupakan faktor penentu daya terima konsumen terhadap produk pangan. Bakso dengan tanpa penambahan gelatin memiliki nilai rasa paling rendah dan bakso dengan penambhan gelatin komersil mendapatkan nilai tertinggi. Hal ini dikarenakan bakso tanpa gelatin memiliki aroma daging kelinci yang menyengat dan tekstur yang kurang kenyal sehingga mempengaruhi rasa yang dihasilkan karena tidak adanya penambahan gelatin. Bakso dengan penambahan gelatin komersil memiliki nilai rasa lebih tinggi dibanding gelatin kulit kelinci karena gelatin kulit kelinci yang dihasilkan memiliki rasa sedikit masam dan nilai viskositas yang lebih rendah dibanding gelatin komersil, sehingga mempengaruhi rasa bakso kelinci yang dihasilkan. Menurut Winarno (2002) rasa banyak ditentukan oleh formulasi yang digunakan dan tidak terlalu dipengaruhi oleh proses pengolahan.

Kekenyalan

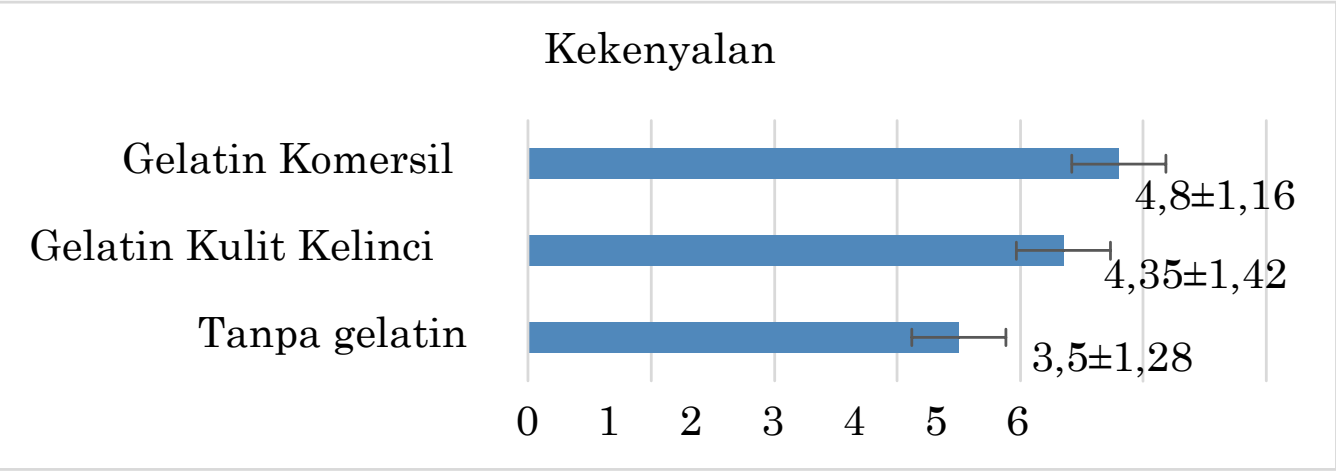

Gambar 8. Histogram Rerata Nilai Organoleptik Kekenyalan Pada Bakso Kelinci

Kekenyalan merupakan bagian pembentuk tekstur yang merupakan faktor penentu daya terima konsumen terhadap produk pangan. Menurut SNI 01- 
3818-1995 menyatakan bahwa bakso yang baik adalah bakso yang memiliki kekenyalan yang tinggi. Dapat dilihat pada gambar diatas bahwa nilai tertinggi kekenyalan dari panelis adalah pada dengan penambahan gelatin komersial dan nilai terendah pada bakso tanpa penambahan gelatin. Hal ini dikarenakan gelatin merupakan protein yang mampu mengikat air sehingga bakso dengan penambahan gelatin memiliki kadar air yang lebih rendah dan tekstur yang lebih kenyal.

\section{Kenampakan}

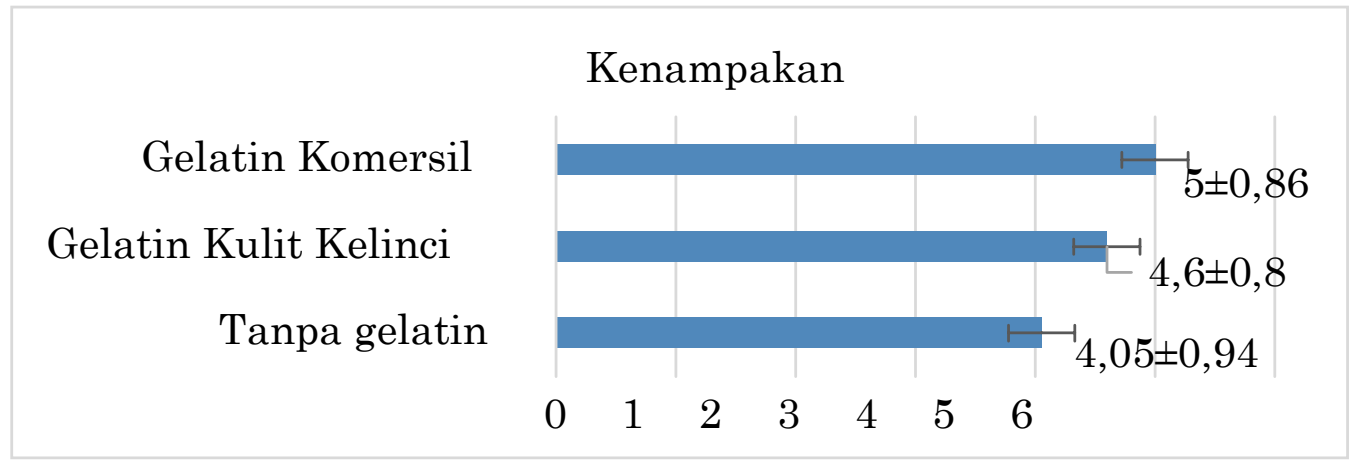

Gambar 9. Histogram Rerata Nilai Organoleptik Kenampakan Pada Bakso Kelinci

Kenampakan merupakan salah satu daya tarik konsumen terhadap suatu produk pangan sebelum rasa. Bakso dengan penambahan gelatin memiliki kenampakan permukaan yang bulat dan halus. Sedangakan bakso dengan tanpa penambahan gelatin memiliki kenampakan yang kasar dan lembek. Menurut Soeparno (2005) yang menyatakan bahwa aspek yang menjadi peilaian dari produk bakso adalah kasar atau halusnya produk bakso yang dihasilkan. Penambahan gelatin pada pembuatan bakso mengakibatkan kadar air pada bakso menurun, sehingga bakso yang dihasilkan memiki tekstur yang halus dan kompak.

\section{KESIMPULAN}

Penggunaan jenis pelarut yang berbeda berpengaruh nyata terhadap rendemen, kadar air, kadar abu, kadar protein, pH, dan kekuatan gel. Penggunaan suhu ekstraksi yang berbeda berpengaruh nyata terhadap rendemen, kadar air, kadar abu, kadar protein, dan viskositas. Bakso kelinci dengan penambahan gelatin kulit kelinci lokal Jawa, gelatin komersil dan tanpa penambahan gelatin berpengaruh nyata terhadap nilai kadar air, kadar protein dan tekstur. 


\section{REFERENSI}

Aberle, D.E., J.C. Forrest, DE Gerrard and E.W. Mills. 2001. Principles of Meat Science. Fourth Edition. W. H. Freeman and Company. San Fransisco, United States of America.

Agustin, A. T. 2013. Gelatin Ikan : Sumber, Komposisi Kimia dan Potensi Pemanfaatannya. Jurnal media teknologi hasil perikanan. 1(2):44-46.

Astawan M, Hariyadi P, Mulyani A. 2002. Analisis Sifat Rheologi Gelatin dari Kulit Ikan Cucut. Jurnal Teknologi Industri Pangan 13(1): 38-46.

Astawan, M. 2003. Tetap Sehat dengan Produk Makanan Olahan. PT. Tiga Serangkai Pustaka Mandiri.. Solo.

Badan Pusat Statistik. 2018. Populasi Ternak Menurut Jenis Ternak. Malang GMIA. 2012. Gelatin Handbook. Gelatin Manufacturers Institute of America.

Hastutiningrum, S. 2009. Pemanfaatan Limbah Kulit Split Industri Penyamakan Kulit untuk Glue dengan Hidrolisis Kolagen. Jurnal Teknologi. 2 (2):208-212.

Kolodziejska,I.,E. Skierka, M. Sadowska, W. Kolodziejski and C. Niecikowska. 2007. Effect Of Extraction Time and temperatur on Yield of Gelatin from Different Fish Offal. Food Chemistry.,107:700-706

Mulyani T., Sudaryati, Rahmawati SF. 2012. Hidrolisis Gelatin Tulang Ikan

Nurilmala, M., 2006, Perbaikan Nilai Tambah Limbah Tulang Ikan Tuna (Thunnus sp) Menjadi Gelatin serta Analisis Fisika Kimia, Laporan Penelitian, IPB, Bogor.

Retno D.T. 2012. Pembuatan Gelatin Dari Tulang Ayam Boiler dengan Proses Hidrolia. Prosiding Seminar Nasional Aplikasi Sains \& Teknologi (SNAST) Periode III ISSN: 1979-911X. Program Studi Teknik Kimia, Universitas Pembangunan Nasional, Veteran

Sartika D. 2009. Pengembangan Produk Marshmallow dari Gelatin Ikan Kakap Merah (Lutjanus Sp.). Skripsi. Fakultas Perikanan dan Ilmu Kelautan, Institut Pertanian Bogor.

SNI 01-3735.1995. Mutu dan Cara Uji Gelatin. Badan Standarisasi Nasional. Jakarta.

SNI 01-3818. 2004. Mutu Bakso Daging. Dewan Standardisasi Nasional, Jakarta

Soeparno. 2005. Ilmu dan teknologi daging cetakan keempat. Gadjah Mada University Press, Yogyakarta.

Sompie, M., Mirah, A.D., \& Karisoh, L.C.H.M. 2015. Pengaruh perbedaan Suhu Ekstraksi Terhadap Karakteristik Gelatin Kulit Kaki Ayam. Gelatin/792795.

Winarno, FG. 2002. Kimia Pangan dan Gizi. Gramedia. Jakarta.

Zahro, 2013. Analisis Mutu Pangan dan Hasil Pertanian. Universitas Jember. Jawa Timur. 